\title{
Geneticizing Bantu: Historical Insight or Historical Trilemma?
}

\author{
Manfred K. H. Eggert*
}

This paper is devoted to the much debated problem of the expansion of Bantu languages over most of the southern half of Africa. Apart from being a major lingustic phenomenon it is a culture-historical and, more specifically, an archaeological topic as well. The reasoning focuses on three aspects: (1) Bantu languages; (2) rainforest archaeology; and (3) Bantu genetics. While the Bantu language dispersal and sub-Saharan archaeology are in some sense historically linked, Bantu genetics is a kind of 'newcomer so the field. As the title indicates, the impact of molecular anthropology on finding an answer to the Bantu expansion - here epitomized by the term rgeneticizing Bantu - claims some importance in this presentation. It has to be stressed, however, that human genetics is by no means the principal topic here. Rather, the emphasis lies on the interplay between Bantu linguistics, archaeology and Bantu genetics. Consequently, it is the combination of all three which is at stake. As the subtitle puts it: we may well ask whether this trinity leads jointly to historical insight or hides a historical trilemma. The paper tries to enumerate some basic points of each field. Likewise, it aims to assess each field's strengths and weaknesses in order to arrive at an answer to the subtitle's question.

Keywords: historical linguistics; prehistoric archaeology; molecular genetics; sub-Saharan Africa; Central African rainforest; Bantu languages; rainforest archaeology; Bantu genetics; Münchhausen trilemma.

\section{Introduction}

The problem at the heart of this contribution involves three disciplines, that is: Bantu linguistics as a field of historical linguistics, sub-Saharan archaeology as a field of prehistoric archaeology, and Bantu genetics as a specialty of molecular genetics. Each of these subfields is highly complex and consequently the domain of rather specialized cultural and molecular anthropologists. Generally, as, for instance, Peter Robertshaw has stressed, ${ }^{1}$ the mutual understanding of each other's units of analysis, methodologies and theoretical underpinnings is rare. Hence, regarding the Bantu languages, one wonders about the potential for solving their dispersal from some homeland in northwestern Central Africa to over most of the southern half of Africa. For almost six decades, linguists and archaeologists have been

\footnotetext{
* Correspondence details: Manfred K. H. Eggert, Institut für Ur- und Frühgeschichte, und Archäologie des Mittelalters, Eberhards-Karls-Universität Tübingen, Schloss Hohentübingen, 72070 Tübingen, Germany. Email: manfred. eggert@uni-tuebingen.de.

1 Robertshaw, African Archaeology, 100-101.
} 
engaged in resolving this enigma. ${ }^{2}$ In recent years, it has especially been linguists in cooperation with geneticists and other scholars such as archaeobotanists, geographers and (although rarely so) archaeologists who have been active in bridging the interpretative gap created by different data and different procedures. ${ }^{3}$ Unfortunately, however, such cooperations should not, a priori, be considered well-integrated interdisciplinary endeavors. ${ }^{4}$

This paper aims at a relatively high level of abstraction. Rather than becoming immersed here in summarizing and analyzing ongoing work in detail - which would not be possible considering the complexity of the arguments and the space allotted - only a very brief general summary of each field is intended. ${ }^{5}$ The main focus of the following concerns the innate potential of each field to generate a solution to the so-called "Bantu Expansion" as a major historical phenomenon in the southern half of Africa. Thus, the question is whether or not the current state of the art gives reason to be optimistic in this regard. The contribution is organized along three lines of reasoning: (1) Bantu languages, (2) rainforest archaeology and (3) Bantu genetics. For a start, some rather general aspects of the historical reconstruction of Bantu languages and related problems will be discussed. Then the argument will switch to the second line, namely, equatorial rainforest archaeology. The archaeology of this habitat is of some importance in the context of the expansion of Bantu languages. This is followed by the third line of reasoning, the relevance of molecular genetics in the context of linguistics and archaeology. ${ }^{6}$ In conclusion, an attempt will be made to bind together the different strands of the argument and relate them to the heading of this paper.

However, to allow for an understanding of the perhaps somewhat enigmatic title of this paper, the historic personality of the Baron von Münchhausen ${ }^{7}$ needs to be introduced here. Later, von Münchausen, or rather one of his tall tales, will help to integrate the reasoning of this paper.

\section{Hieronymus Carl Friedrich Freiherr von Münchhausen}

Hieronymus Carl Friedrich Freiherr von Münchhausen was born in 1720 at his father's estate in Bodenwerder in the Duchy of Brunswick-Lüneburg (now within the state of Lower Saxony in Germany). He served as an officer in the Russian cavalry and participated in the RussianTurkish war. After having retired to his estate in Bodenwerder he died there in 1797. In his later years, he became a legendary figure in aristocratic circles of the region, since he used to entertain his guests with extraordinary tall tales of his travels and adventures during and

2 See Eggert, Bantu Problem and African Archaeology.

3 See, e.g., Bostoen et al., Middle to Late Holocene Paleoclimatic Change; de Filippo et al., Bringing Together Linguistic and Genetic Evidence; Grollemund et al., Bantu Expansion; Kahlheber et al., Early Plant Cultivation; Li et al., Genetic Variation; Pakendorf et al., Molecular Perspectives on the Bantu Expansion.

4 As an example might serve Bostoen et al., Middle to Late Holocene Paleoclimatic Change; see Eggert, Comment on Bostoen et al.

5 For an in-depth consideration of the underlying difficulties the reader is referred to Eggert, Bantu und Indogermanen.

6 The verb sto geneticizer which I use in this context and, more specifically, in the main title of this paper, is certainly uncommon; it was invented here for the sake of my reasoning.

7 In the English-speaking world he is known as >Baron Munchausen<; however, I am using the original German version of von Münchhausen's patronym. 
after his military service. Münchhausen never wrote down any of these stories, but some of them were anonymously put into literary form in a series of newspaper articles in German. Later published in English, they were soon translated into other languages and became a great success. From the very beginning, the various editions and re-editions transformed Münchhausen into a fabulous fictional character whose glamor and bravado made him much more interesting than the real-life baron had ever been. However, in Germany the two barons remained and remain largely intertwined as attested by the nickname Lügenbaron (literally 'Baron of Lies`) given to the Bodenwerder Münchhausen. Here is one of the baron's tall tales:

"At another time I wanted to jump with my horse over a morass which did not appear as wide to me as it actually was when I was in the middle of the jump. Hovering in the air I thus turned back to from where I started so as to take a longer run-up. Nonetheless, I again jumped too short and found myself up to my neck in the morass near its other edge. Here I surely would have perished were it not for the strength of my own arm such that I pulled myself out on my own pigtail, together with my horse, which I took firmly between my knees. ${ }^{8}$

This is what one might call a three-dimensional tale in that there are three clearly identifiable, though improbable, contentions: first, Münchhausen turns his horse in the middle of the jump, second, he pulls himself out of the morass on his own pigtail, and third, in taking the horse firmly between his knees he rescues it as well. ${ }^{9}$ In fact, the whole setting implies what the German sociologist and philosopher Hans Albert has called this the MünchhausenTrilemma ${ }^{10}$ As said, I will come back to that later.

\section{Bantu Languages}

Since the Bantu languages are the focus of this paper, some basic points need to be enumerated. The study of the ancestry of languages and thus their internal and spatial change over time falls within the field of historical linguistics. Its foundation goes back to the nineteenth century, when in Germany, the Indo-European languages were studied by what came to be known as the "comparative method". In the 1850s, the German linguist Wilhelm Heinrich Immanuel Bleek (1827-1875), who resided in the Cape Colony, discovered the genetic relationships of a number of languages spoken in the southern half of Africa. He termed them "Bantu«, after the Zulu word aba-ntu which means "men". Today, the number of Bantu languages is estimated to be between about 300 and $680,{ }^{11}$ with a tendency to settle for about 500. ${ }^{12}$ Bantuists agree that the Ursprache of Bantu, that is proto-Bantu, originated somewhere in the borderland of what is now Nigeria and Cameroon (Fig. 1). ${ }^{13}$

8 Translated by the author from Anonymous, Wunderbare Reisen, 54-55.

9 In both the English and the German Wikipedia there are several informative entries on von Münchhausen.

10 Albert, Traktat über kritische Vernunft, esp. 13-15.

11 See, e.g. Nurse, Contributions of Linguistics, 367; Nurse, Survey Report for the Bantu Languages. Nurse (Contributions of Linguistics, 367) himself estimates the number of Bantu languages »sligthly more than 300 «.

12 See, e.g., Bostoen et al., Middle to Late Holocene Paleoclimatic Change, 354.

13 For the major lines of the development of Bantu linguistics and its relationship to archaeology see Eggert, Bantu Problem and African Archaeology. 


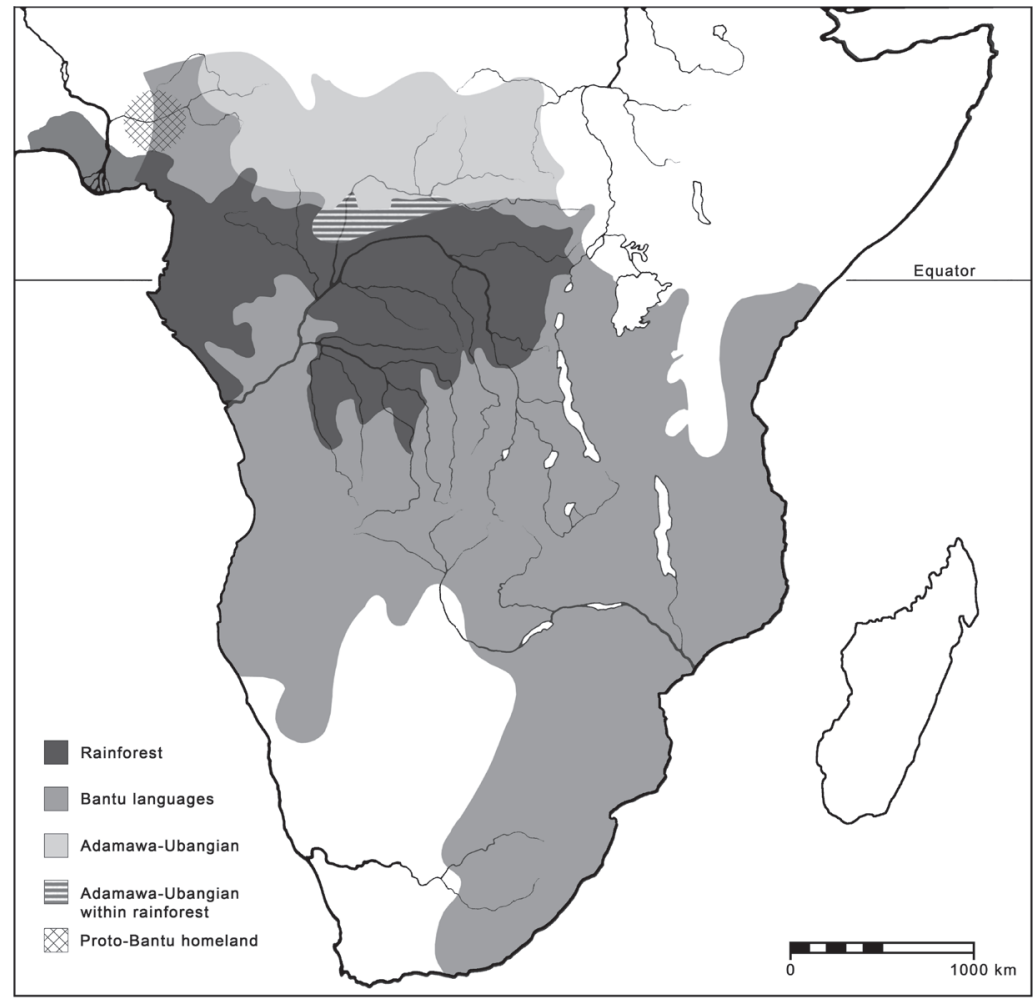

Fig.1: Distribution of Bantu and Adamawa-Ubangian languages in relation to the rainforest (after Eggert et al., Pits, Graves and Grains, 275, fig. 1)

The most hotly debated question regarding Bantu concerns the mechanisms and routes of its dispersal over most of sub-Saharan Africa. This question represents one of the continent's greatest linguistic and cultural-historical problems. Unfortunately, from the very beginning, the debate was marred by intermingling linguistic and archaeological arguments, in a word, by circular reasoning. ${ }^{14}$ The whole problem of Bantu language origins and dispersal bears a striking resemblance to that of the Indo-European languages. In a recent paper, both were analyzed together with archaeo- or historical genetics, in considerable detail. ${ }^{15}$ Principally, language change and language dispersal have been generalized in a number of models. The main models discussed today include the so-called »migration model«, the "wave-of-advance model«, the "discontinuous spread model«, the "wave model« and the "language shift" or »dominance model«. Except for the wave model, all others opt for concrete migrations of people, although on different scales. The wave model assumes language dispersal via contact between speech communities, that is, by means of diffusion rather than migration. ${ }^{16}$ With respect to Bantu, most if not all bantuists figure its dispersal in terms of migratory movements of some kind. In recent years, Koen Bostoen in particular has been intensely working on this. ${ }^{17}$

14 See, e.g., Eggert, Bantu Problem and African Archaeology, 307-312.

15 Eggert, Bantu und Indogermanen.

16 On the modeling of language spread see Eggert, Bantu und Indogermanen, 14-17, and Eggert, Bantu Problem and African Archaeology, 317. Both are referring back to Nurse, Contributions of Linguistics.

17 See, e.g., Bostoen et al., Middle to Late Holocene Paleoclimatic Change, 358-362, with figs. 2 and 3; Pakendorf et al., Molecular Perspectives on the Bantu Expansion, 54-57, with figs. 1 and 2. 
In the following, I will focus on the Central African rainforest for two reasons: (1) because of my extensive first-hand experience as an archaeologist with this ecosystem, and (2) because the rainforest represents an almost homogeneous linguistic territory. Except for some languages of the Adamawa-Ubangian language family spoken in its northern part, the forest is peopled by Bantu-speaking populations (see Fig. 1). From a linguistic point of view there are a number of more or less divergent hypotheses of how Bantu came to be spread throughout the forest. Since this immense biome is counted among the first territories to have been settled by Bantu speakers, it is closely linked with the initial dispersal of Bantu from its proto-Bantu homeland in northwestern Central Africa. In assessing the various hypotheses of the penetration of Bantu speakers into the tropical forest, as well as their subsequent splittings, one has to be aware of the temporal dimension of Bantu. Since Bantu languages only came to be written down in dictionaries, grammars, texts and so forth in the nineteenth century, there are no genuine linguistic sources in the narrow historical sense of the term prior to that time. That is to say, Bantu languages are not attested by authentic evidence before the nineteenth century. That is to say, that even the earliest written Bantu material is all but contemporaneous with the temporal context historical Bantu linguists tried to reconstruct. Thus, all Bantu reconstruction is based on the comparative method of historical linguistics (or some derivatives of it) developed in the nineteenth century. By contrast, a number of Indo-European languages are attested to by original texts, some of which go back to the first half of the second millennium BC. ${ }^{18}$ Also, while we are dealing with about 300 to 500 Bantu languages, Indo-European is restricted to about 140 languages, which have been intensely studied since the beginning of the nineteenth century. Today, Indo-European is considered the most exhaustively analyzed language family on a global scale. ${ }^{19}$ The important point to remember here concerns the fact that with regard to Bantu, the comparative method is not capable of furnishing any information on the absolute time depth of the reconstructions achieved by it. As just indicated, these are exclusively based on what one might call a kind of linguistic "presence«. Consequently, this is also true for all speculative efforts of linking all language detachments or splits in the rainforest and elsewhere to an absolute temporal framework. ${ }^{20}$

All attempts of breathing time into Bantu linguistic data - in terms of both relative as well as absolute time - proceeds by means of what linguists call "lexicostatistics « and "glottochronology «. While the first aims at relative time, the second maintains to produce more or less precise time spans in relation to fixed points, that is, absolute time. As has been detailed elsewhere, both procedures have been intensely discussed for decades. While lexicostatistics appears more or less accepted as a means of generating rough relative datings, rare today are those who consider glottochronology a suitable technique for establishing absolute age..$^{21} \mathrm{P}$. Sims-Williams, for example, speaks in this context of »the sglottochronological fallacy«. ${ }^{22}$ As

19 Bußmann, Historisch-vergleichende Sprachwissenschaft, 285-288; Meier-Brügger, Indogermanische Sprachwissenschaft, 133-141.

20 Eggert, Bantu und Indogermanen, 34, with note 116.

21 Thus, the Bantuist Schadeberg, Historical Linguistics, 160, states: »Historical linguistics is strong in relative chronology but has no credible means to provide absolute datings."

22 Sims-Williams, Genetics, Linguistics, and Prehistory, 509. 
of late, however, it is Bayesian statistics in which linguistic reconstructions of phylogenetic language trees are clad as, for instance, in the papers of both Bostoen et al. and Grollemund et $a ._{.}^{23}$ These impressive looking statistics seem to add considerable weight to the argument, but, as Roger Blench claims, behind the "glamorous graphics « lurks »just the discredited old lexicostatistics. ${ }^{24}$ The answer of Bostoen and coauthors, against whom Blench's remark was directed, shows to which degree complex statistical procedures might obscure underlying empirical data. In consequence, the question of what temporal distance might separate us from the reconstructed proto-Bantu is not solvable within historical linguistics. We therefore have to think about other means of getting at the time dimension in regard to the influx of Bantu speakers in the Central African forest and beyond. Quite naturally, as in the case of the Indo-European languages, attention focuses on archaeology. Blench remarked that it is the interplay between linguistics and archaeology that is crucial here. To him, this interplay depends on reconstructible lexical items that bear potential associations with the archaeological record. ${ }^{25}$ Unfortunately, however, associations of this kind are relatively rare and usually do not have much explanatory power. Shared words - as Blench himself is fully aware of ${ }^{26}$ - might as well indicate technical or social change as not have an impact on the archaeological record at all. In this contribution then, archaeology is considered as the second line of reasoning. Since its history of research has been spelled out elsewhere, ${ }^{27}$ there is no point in discussing it here again. Rather, I will briefly comment on the current state of rainforest archaeology, and then move on to archaeo-genetics.

\section{Rainforest Archaeology}

Since 1977 I have been engaged in archaeological fieldwork in the Central African rainforest, which covers parts of the modern states of the Democratic Republic of the Congo (CongoKinshasa for short), the Republic of the Congo (Congo-Brazzaville) and Cameroon. According to current knowledge, pottery-producing groups began to penetrate into the forest at about 800 BC. Between 400 and 300 BC, early ceramics are present over a large area stretching from central Cameroon into the Inner Congo Basin. ${ }^{28}$ However, although widely distributed, this ceramic evidence does not constitute a geographically interrelated net of archaeological sites which one might consider sufficiently dense. Rather, the evidence is spotty, with large gaps of archaeological terra incognita in between. As for shape and decoration, the pottery in question is complex and certainly not homogeneous. Nevertheless, there are some formal and decorative elements that the different ceramic groups have in common. This has led several authors to contemplate a possible relationship on the level of pottery. Others, however, use these similarities to postulate an outright historical connection between the populations which made this pottery. ${ }^{29}$

24 Blench, Comment, 367, an argument which the authors disapproved of: Bostoen et al., Middle to Late Holocene Paleoclimatic Change, 376; see also Dimmendaal, Comment on Bostoen et al., 369.

25 Blench, Language, Linguistics, and Archaeology, 53-54.

26 Blench, Language, Linguistics, and Archaeology,. 54, 60.

27 Eggert, Archaeology of the Central African Rainforest, 185-186, 189-190; Eggert, Bantu und Indogermanen, 25-26.

28 Eggert, Bantu und Indogermanen, 27-28, with fig. 9; Wotzka, Records of Activity, 279-281.

29 Eggert, Bantu und Indogermanen, 25-28. 
Since about the mid-1960s archaeological evidence has been used in many efforts to trace the dispersal of Bantu languages over the southern half of the African continent. As mentioned above, this led to circular reasoning within historical Bantuistics as well as African archaeology. Regarding the Central African forest it was and is tempting to link the influx of farmers and potters with the arrival of Bantu speakers. Unfortunately however, there is no genuine association between languages on the one hand and farming and making pottery on the other. As we all know, this is true for the whole realm of material culture in general. In other words, non-written languages do not leave material traces. In contrast, migrations in the sense of any larger movement of populations - regardless of which language or languages are being spoken by the migrants - can be expected to leave at least some sort of material imprint.

Thus, our argument has gone full circle: in order to lend some plausibility at all to the linkage between the migratory movement of speakers of whatever languages and the material traces of times past, we need to have a well-dated and sufficiently interconnected archaeological record at our disposal. Even then, however, the possibility that these migrants spoke a specific language remains just that: a possibility which might or might not be plausible. At any rate, the current archaeological record in the Central African rainforest is extremely spotty and consequently far from convincing so as to be taken as a reflection of a steady influx of Bantu speakers into the forest, let alone movement on a larger scale. In general, archaeology, with its material record of bygone times, is uniquely suited to provide a rather fine absolute time-scale for phenomena of the past. While, as Scott MacEachern has stressed, historical linguists and geneticists routinely make use of archaeological data and its associated radiocarbon datings, ${ }^{30}$ this does not resolve the inherent difficulty in linking these fields in the first place. But he is certainly right that radiocarbon dating is based upon a fairly well-known physical process, whereas chronological estimates in both historical linguistics and archaeogenetics are dependent on linguistic and biological processes that are "not well-constrained physically«. And, he continues, since archaeological data are so often adopted beyond archaeology, it is all the more important that archaeologists understand the basis and limitations of chronologies proper to these other fields. ${ }^{31}$ Having thus dealt briefly with rainforest archaeology, I will now switch to the third line of my argument. It is constituted by molecular genetics or, rather, to its possible impact on the decipherment of the dispersal of Bantu.

\section{Bantu Genetics}

As archaeo-genetics in general, molecular studies of Bantu-speaking populations are increasing at a rapid pace. The latter are proceeding with a clear historical aim: they want to contribute to, if not to solve, the riddle of the dispersal of Bantu languages. Nevertheless, what Lara B. Scheinfeldt, Sameer Soi and Sarah A. Tishkoff stated in 2010 is still true: the results of studies on genetic variation in Africa and their correlation with cultural and linguistic diversity have not been sufficiently studied yet. ${ }^{32}$ Sometimes, however, geneticists seem to overestimate the historical potential of their field in their common endeavor. ${ }^{33}$

30 MacEachern, Holocene History, 265.

31 MacEachern, Holocene History, 266.

32 Scheinfeldt et al., Working toward a Synthesis, 8931.

33 The Scheinfeldt et al. paper with its pretentious title is a good example. In it, roughly three-quarters of a page are devoted to the "Bantu Expansion " (Scheinfeldt et al., Working toward a Synthesis,) and there the authors inadvertently demonstrate their lack of knowledge of the linguistic and archaeological problems involved. 
Being trained in linguistics as well as in molecular anthropology, Brigitte Pakendorf has recently discussed some important issues involved in linking up historical linguistics and molecular anthropology. She posits a coevolution of genes and languages in that both are passed on by socially interacting males and females. On the other hand, as she stresses, languages are also submitted to contact-induced change. Thus, while genes are passed on only vertically from parents to offspring, culture contact between speech communities enables languages to be influenced on a horizontal level as well. ${ }^{34}$ Since it is not possible to discuss the relationship of historical Bantu linguistics to Bantu genetics here in any detail, the following will concentrate on a few aspects only ${ }^{35}$ First, there is the problem of the origin of the genetic data analyzed. Phrased differently, it is important to know according to which ethnolinguistic criteria the donor groups of the samples were defined..$^{36}$ From general experience it seems fair to say that these definitions, considered from a cultural anthropological and linguistic perspective, are more often than not rather vague. Even more questionable appears the genetic makeup, and thus the genetic variability, within however-defined ethnolingustic groups, let alone the correspondence between ethnolinguistic boundaries and changes within intragroup genetic variability. ${ }^{37}$ Second, we are faced with the problem of how genetic patterning is to be correlated with linguistic patterning and language change. For although genes and languages are passed on through sexual and cultural interaction, there are no genes for language. The capacity of man to principally master any language, however imperfectly, is more than sufficient proof of this point. Third, the current state of the art of molecular genetics in Bantu Africa is all but satisfying. In fact, and especially in central, southwestern and southern Africa, only a fairly restricted number of genetically studied farming groups has been examined yet. ${ }^{38}$ The same applies to Bantu speakers in eastern Africa. ${ }^{39}$ While being generally true for the tropical rainforest as well, this applies most notably to the Congo Basin..$^{40}$ Thus, the scarcity of genetic data is directly related to the potential for comparison with the quantity and quality of other datasets, be they linguistic or archaeological. But even if such comparisons were to be established, we would still be left with the question as to whether "patterning in one dataset has anything to do with patterning in the other, " as Scott MacEachern put it. ${ }^{41}$ Fourth and last, since the expansion of the Bantu languages over the southern half of Africa is a historical phenomenon, the historical impact of genetic data seems important. While it is one thing to agree on the immense temporal dimension inherent in genes, it is quite another to come up with genuine ancient DNA from Bantu Africa. Needless to say that due to the acidity of tropical soils, human skeletal material is, if at all, almost nonexistent beyond a very narrow temporal limit of two or three centuries at most. In contrast, despite the inbuilt time factor in genes, modern DNA is contemporary and thus the outcome of an inextricably complicated mixture of genetic and social factors. Although there

34 Pakendorf, Historical Linguistics and Molecular Anthropology, 627-628.

35 For a more detailed discussion see Eggert, Bantu und Indogermanen, 34-38.

36 Pakendorf, Historical Linguistics and Molecular Anthropology, 630.

37 MacEachern, Genetics and Archaeology, 68.

38 MacEachern, Genetics and Archaeology, 67-68.

39 See, e.g., Pakendorf et al., Molecular Perspectives on the Bantu Expansion, 58, 59, 61.

40 DeFilippo et al., Bringing Together Linguistic and Genetic Evidence, 3258, fig. 2b.

41 MacEachern, Genetics and Archaeology, 67. 
are a number of techniques of estimating genetic distance, ${ }^{42}$ one wonders how far the quality and quantity of the data at hand from Bantu Africa will lead to convincing results. It may be noted in passing, that when it comes to measuring linguistic distance, Pakendorf is rather skeptical. However, her proposition of the coevolution of genes and languages is dependent on correlations between genetic and linguistic distances. ${ }^{43}$ This last point is worth keeping in mind, since it implies that the coevolution of genes and languages is all but a foregone conclusion. That is to say, while coevolution is possible, its actual presence in each particular case has to be demonstrated rather than assumed. Consequently, a mismatch between genetic and linguistic data does not appear as telling as it is represented in the literature. It would be misleading to look for an explanation only in terms of language shift or intermarriage in which the married-in maintain their language. ${ }^{44}$ Rather, it seems to be the coevolution model which is at stake here.

Finally, MacEachern in his paper on genetics and archaeology has directed attention - as has Robertshaw before him ${ }^{45}$ as well as Pakendorf in her paper on historical linguistics and molecular anthropology - to the necessity of interdisciplinary work.$^{46}$ One could only agree, since otherwise we would be constantly faced with a situation strongly reminiscent of the intermingling of linguistic and archaeological reasoning of times past. In fact, circular reasoning seems forever looming nearby were it not for the special attention given to that danger. ${ }^{47}$ There is a certain tendency to refer oneself to the conclusions of a paper of another discipline in the search for supporting arguments of one's own case. With regard to molecular genetics, MacEachern has termed this the "Last Paragraphs Problem", since it is often in the concluding section of molecular papers where genetic patterns are linked to historical processes. ${ }^{48}$ Needless to say, the same is true for historical linguistics and archaeology as well. Also, Robertshaw does not quite see how molecular genetics fits into his proposed new, potentially interdisciplinary, approaches. ${ }^{49}$ According to him, genetic data tell us something about the biotic outcomes of past events but much less about African history as such..$^{50}$ It has to be stressed, however, that his concept of "history « is a rather rigid one, revolving, as it were, around the notions of "how « and "why". In this, neither archaeology nor historical linguistics are any better off than molecular genetics. As far as the current situation is concerned, it is quite obvious that with regard to the Bantu problem, molecular genetics and historical linguistics have been cooperating rather intensely in recent years in publishing research papers. Under these circumstances it is all the more surprising that archaeology, as the only discipline capable of generating authentic historical evidence - that is, evidence which is part and parcel of the time it is supposed to elucidate - is not or is only rarely being cited in this context. ${ }^{51}$

43 Pakendorf, Historical Linguistics and Molecular Anthropology, 628-629.

44 But see Pakendorf, Historical Linguistics and Molecular Anthropology, 630.

45 Robertshaw, African Archaeology, 100-102.

46 MacEachern, Genetics and Archaeology, 69, 74; Pakendorf, Historical Linguistics and Molecular Anthropology, 630, 631.

47 See also Eggert, Comment on Bostoen et al., 370 on this.

48 MacEachern, Genetics and Archaeology, 69.

49 Robertshaw, African Archaeology, 101.

50 Robertshaw, African Archaeology, 100, 102.

51 See, e.g., Pakendorf, Historical Linguistics and Molecular Anthropology, 631, where in a number of fields mentioned archaeology is missing. 


\section{Insight or trilemma?}

It has been argued here that historical Bantu linguists agree on an origin of the Bantu languages in northwestern Central Africa. If so, the speakers must have penetrated from this Urheimat into the equatorial rainforest on their way south. However, although there are almost no non-Bantu languages spoken in the forest, we do not possess any material evidence - which, under the given circumstances, could only be ceramics - to infer any kind of population movement. Likewise, the link between Bantu languages and molecular genetics appears as tenuous as that between languages and material culture. In any case, for want of ancient DNA, genetics is being barred from basing its arguments on authentic evidence in the sense explicated above. As mentioned, this is true for historical linguistics as well.

To sum up, it is indeed far from being established that the molecular, linguistic and archaeological data used in the Bantu expansion endeavor can rightly be considered a reflection of a common historical process..$^{52}$ As Blench observed, wide-ranging correlations of archaeo-genetics, archaeology and historical linguistics seem still to be far in the future. ${ }^{53} \mathrm{In}$ other words: (1) we are a far cry from linking what might be called the inherent "presence» of Bantu linguistics to the authentic material evidence of archaeology; (2) there appears to be about an equal distance between the extraordinarily spotty molecular dataset and the much more solidly constituted set of Bantu languages; and (3) there is as yet not even a hint of any linking of contemporary molecular data to the archaeologically documented human past.

At this juncture it is time to come back to the Baron von Münchhausen who was briefly characterized earlier. Hans Albert has demonstrated that the aim of any process of epistemological justification resides in establishing the truth of the respective propositions and, consequently, their formulation. Truth has to be based on proof. However, as soon as a justification, in other words proof, is demanded for each proposition, this implies first, either an infinite regress; or, second, a logical circle in the deduction; or, third, an arbitrary suspension of the principle of sufficient reason. ${ }^{54}$ As mentioned, this is what Albert, with direct reference to the Münchhausen tale quoted above, has called the "Münchhausen-Trilemma«. Considering the state of the elucidation of the Bantu problem, one is very much reminded of the Münchhausen trilemma. Or, to put it differently, the joint efforts of historical Bantu linguistics and archaeology have not come up with convincing solutions yet. Unfortunately, the impact of molecular genetics in recent years has not significantly changed the overall picture. Although "issues of scale« and, by implication, »Big Science directed toward Big Questions, " as MacEachern observes, ${ }^{55}$ play a role here, they are certainly not the key to the problem. Rather, as I have attempted to show here, molecular genetics have added another "procedural« puzzle ${ }^{56}$ so that instead of a dilemma, we may now confidently speak of a trilemma.

\section{Acknowledgements}

I would like to thank Dirk Seidensticker (Tübingen) for the preparation of the figure. Also, I am grateful to an anonymous reviewer who caused me to elaborate on some insufficiently developed points in the original manuscript. 


\section{References}

Albert, Hans, Traktat über kritische Vernunft, Die Einheit der Gesellschaftswissenschaften: Studien in den Grenzbereichen der Wirtschafts- und Sozialwissenschaften 9 (Tübingen, 1968).

Anonymous, Wunderbare Reisen zu Wasser und Lande, Feldzüge und lustige Abentheuer des Freyherrn von Münchhausen, wie er dieselben bey der Flasche im Cirkel seiner Freunde selbst zu erzählen pflegt. Aus dem Englischen nach der neuesten Ausgabe übersetzt, hier und da erweitert und mit noch mehr Kupfern gezieret, (London, 1786, reprint Leipzig, 1925).

Blench, Roger, Comment on Bostoen et al., Middle to Late Holocene Palaeoclimatic Change, Current Anthropology 56/3 (2015) 367-368.

Blench, Roger, Language, Linguistics, and Archaeology: Their Integration in the Study of African Prehistory, in: Peter Mitchell and Paul Lane (eds.), The Oxford Handbook of African Archaeology (Oxford, 2013) 49-63.

Bostoen, Koen, Clist, Bernard, Doumenge, Charles, Grollemund, Rebecca, Hombert, Jean-Marie, Koni Muluwa, Joseph and Maley, Jean, Middle to Late Holocene Paleoclimatic Change and the Early Bantu Expansion in the Rain Forests of Western Central Africa. With Comments and a Reply by the Authors, Current Anthropology 56/3 (2015) 354-384.

Bußmann, Hadumod, Historisch-vergleichende Sprachwissenschaft, in: Hadumod Bußmann (ed.), Lexikon der Sprachwissenschaft, (4th edition), (Stuttgart, 2008) 264-265.

Dimmendaal, Gerrit J., Comment on Bostoen et al., Middle to Late Holocene Palaeoclimatic Change, Current Anthropology 56/3 (2015) 368-369.

Eggert, Manfred K. H., Comment on Bostoen et al., Middle to Late Holocene Palaeoclimatic Change, Current Anthropology 56/3 (2015) 369-370.

Eggert, Manfred K. H., The Archaeology of the Central African Rainforest: Its Current State, in: Colin Renfrew and Paul Bahn (eds.), The Cambridge World Prehistory, Vol. 1 (New York, 2014) 183-203.

Eggert, Manfred K. H., Bantu und Indogermanen: Zur vergleichenden Anatomie eines sprach- und kulturgeschichtlichen Phänomens, Saeculum 62/1 (2012) 1-63.

Eggert, Manfred K. H., The Bantu Problem and African Archaeology, in: Ann B. Stahl (ed.), African Archaeology: A Critical Introduction, Blackwell Studies in Global Archaeology (Malden/ MA, 2005) 301-326.

Eggert, Manfred K. H., Höhn, Alexa, Kahlheber, Stefanie, Meister, Conny, Neumann, Katharina and Schweizer, Astrid, Pits, Graves and Grains: Archaeological and Archaeobotanical Research in Southern Cameroun, Journal of African Archaeology 4/2 (2006) 273-298.

de Filippo, Cesare, Bostoen, Koen, Stoneking, Mark and Pakendorf, Brigitte, Bringing Together Linguistic and Genetic Evidence to Test the Bantu Expansion, Proceedings of the Royal Society B, Biological Sciences 279 (2012) 3256-3263.

Grollemund, Rebecca, Branford, Simone, Bostoen, Koen, Meade, Andrew, Venditti, Chris and Pagel, Mark, Bantu Expansion Shows that Habitat Alters the Route and Pace of Human Dispersals, Proceedings of the National Academy of Sciences of the United States of America (PSNA) 112/43 (2015) 13296-13301.

Kahlheber, Stefanie, Bostoen, Koen and Neumann, Katharina, Early Plant Cultivation in the Central African Rainforest: First Millennium BC Pearl Millet from South Cameroon, Journal of African Archaeology 7/2 (2009) 253-72. 
Li Sen, Schlebusch, Carina and Jakobsson, Mattias, Genetic Variation Reveals Large-Scale Migration during the Expansion of Bantu-Speaking Peoples, Proceedings of the Royal Society B, Biological Sciences 281 (2014) 1-9.

MacEachern, Scott, Genetics and Archaeology, in: Peter Mitchell and Paul Lane (eds.), The Oxford Handbook of African Archaeology (Oxford, 2013) 63-76.

MacEachern, Scott, The Holocene History of the Southern Lake Chad Basin: Archaeological, Linguistic and Genetic Evidence, African Archaeological Review 29/2-3 (2012) 253-271.

Meier-Brügger, Michael, Indogermanische Sprachwissenschaft, (9th edition), (Berlin, 2010).

Nurse, Derek, The Contributions of Linguistics to the Study of History in Africa, Journal of African History 38 (1997) 359-391.

Nurse, Derek, A Survey Report for the Bantu Languages, SIL International 2001 (2002). Retrieved on 23 July 2016: www.sil.org/silesr/2002/016/SILESR2002-016.htm.

Pakendorf, Brigitte, Historical Linguistics and Molecular Anthropology, in: Claire Bowern and Bethwyn Evans (eds.), The Routledge Handbook of Historical Linguistics (London, 2015) 627-641.

Pakendorf, Brigitte, Bostoen, Koen and de Filippo, Cesare, Molecular Perspectives on the Bantu Expansion: A Synthesis, Language Dynamics and Change 1 (2011) 50-88.

Robertshaw, Peter, African Archaeology, Multidisciplinary Reconstruction of Africa's Recent Past, and Archaeology's Role in Future Collaborative Research, African Archaeological Review 29/2-3 (2012) 95-108.

Schadeberg, Thilo C., Historical Linguistics, in: Derek Nurse and Gérard Philippson (eds.), The Bantu Languages (London, 2003) 143-163.

Scheinfeldt, Laura B., Soi, Sameer and Tishkoff, Sarah A., Working toward a Synthesis of Archaeological, Linguistic, and Genetic Data for Inferring African Population History, Proceedings of the National Academy of Sciences of the United States of America (PSNA) 107, suppl. 2 (2010) 8931-8938.

Sims-Williams, P., Genetics, Linguistics, and Prehistory: Thinking Big and Thinking Straight, Antiquity 72 (1998) 505-527.

Wotzka, Hans-Peter, Records of Activity: Radiocarbon and the Structure of Iron Age Settlement in Central Africa, in: Hans-Peter Wotzka (ed.), Grundlegungen: Beiträge zur europäischen und afrikanischen Archäologie für Manfred K. H. Eggert (Tübingen, 2006) 271-289. 